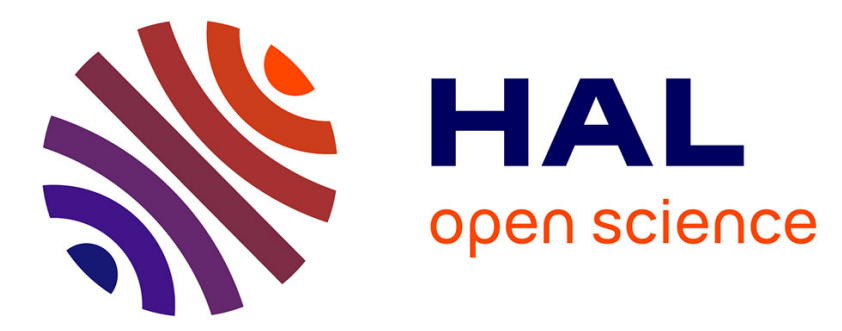

\title{
Bilirubin oxidase based enzymatic air-breathing cathode: Operation under pristine and contaminated conditions
}

\author{
Carlo Santoro, Sofia Babanova, Benjamin Erable, Andrew Schuler, Plamen
}

Atanassov

\section{- To cite this version:}

Carlo Santoro, Sofia Babanova, Benjamin Erable, Andrew Schuler, Plamen Atanassov. Bilirubin oxidase based enzymatic air-breathing cathode: Operation under pristine and contaminated conditions. Bioelectrochemistry, 2016, vol. 108, pp. 1-7. 10.1016/j.bioelechem.2015.10.005 . hal-01304959

\section{HAL Id: hal-01304959 \\ https://hal.science/hal-01304959}

Submitted on 20 Apr 2016

HAL is a multi-disciplinary open access archive for the deposit and dissemination of scientific research documents, whether they are published or not. The documents may come from teaching and research institutions in France or abroad, or from public or private research centers.
L'archive ouverte pluridisciplinaire HAL, est destinée au dépôt et à la diffusion de documents scientifiques de niveau recherche, publiés ou non, émanant des établissements d'enseignement et de recherche français ou étrangers, des laboratoires publics ou privés. 


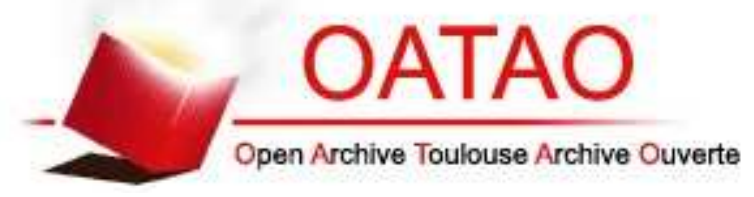

\section{Open Archive TOULOUSE Archive Ouverte (OATAO)}

OATAO is an open access repository that collects the work of Toulouse researchers and makes it freely available over the web where possible.

This is an author-deposited version published in : http://oatao.univ-toulouse.fr/ Eprints ID : 15709

To link to this article : DOI : 10.1016/j.bioelechem.2015.10.005 URL : http://dx.doi.org/10.1016/j.bioelechem.2015.10.005

To cite this version : Santoro, Carlo and Babanova, Sofia and Erable, Benjamin and Schuler, Andrew and Atanassov, Plamen Bilirubin oxidase based enzymatic air-breathing cathode: Operation under pristine and contaminated conditions. (2016)

Bioelectrochemistry, vol. 108. pp. 1-7. ISSN 1567-5394

Any correspondence concerning this service should be sent to the repository administrator: staff-oatao@ listes-diff.inp-toulouse.fr 


\title{
Bilirubin oxidase based enzymatic air-breathing cathode: Operation under pristine and contaminated conditions
}

\author{
Carlo Santoro a,b,1, Sofia Babanova ${ }^{\mathrm{a}, 1}$, Benjamin Erable ${ }^{\mathrm{c}}$, Andrew Schuler ${ }^{\mathrm{b}}$, Plamen Atanassov ${ }^{\mathrm{a}, *}$ \\ a Department of Chemical \& Biological Engineering, Center for Micro-Engineered Materials (CMEM), University of New Mexico, Albuquerque, NM 87131, USA \\ ${ }^{\mathrm{b}}$ Department of Civil Engineering, Center for Emerging Energy Technologies (CEET), University of New Mexico, Albuquerque, NM 87131, USA \\ c Laboratoire de Génie Chimique, CNRS, Université de Toulouse, 4 allée Emile Monso, 31029 Toulouse, France
}

Keywords:

Bilirubin oxidase

Oxygen reduction reaction

Enzymes durability

PBS conditions

Pollutants

\begin{abstract}
A B S T R A C T
The performance of bilirubin oxidase (BOx) based air breathing cathode was constantly monitored over 45 days. The effect of electrolyte composition on the cathode oxygen reduction reaction (ORR) output was investigated. Particularly, deactivation of the electrocatalytic activity of the enzyme in phosphate buffer saline (PBS) solution and in activated sludge (AS) was evaluated. The greatest drop in current density was observed during the first 3 days of constant operation with a decrease of $\sim 60 \mu \mathrm{Acm}^{-2} \mathrm{day}^{-1}$. The rate of decrease slowed to $\sim 10 \mu \mathrm{Acm}{ }^{-2} \mathrm{day}^{-1}$ (day 3 to 9 ) and then to $\sim 1.5 \mu \mathrm{Acm}^{-2}$ day $^{-1}$ thereafter (day 9 to 45 ). Despite the constant decrease in output, the BOx cathode generated residual current after 45 days operations with an open circuit potential (OCP) of $475 \mathrm{mV}$ vs. $\mathrm{Ag} / \mathrm{AgCl}$. Enzyme deactivation was also studied in AS to simulate an environment close to the real waste operation with pollutants, solid particles and bacteria. The presence of low-molecular weight soluble contaminants was identified as the main reason for an immediate enzymatic deactivation within few hours of cathode operation. The presence of solid particles and bacteria does not affect the natural degradation of the enzyme.
\end{abstract}

\section{Introduction}

Enzymes are large, generally proteinaceous, biological molecules that catalyze specific reactions transforming substrates into products. Like all catalysts, they can increase reaction rates by decreasing the reaction activation energies. Enzymes are widely used by the scientific community mainly due to their selectivity and specificity [1]. One set of enzymes, belonging to the oxidoreductases family, can reduce oxygen into water performing the "so called" oxygen reduction reaction (ORR) [2-3]. The steps involved in the reduction mechanism of oxygen have been previously described in details $[4,5]$.

Multi-copper oxidases (MCOs) are among the enzymes able to reduce oxygen to water [6]. The most known and heavily explored MCOs are ascorbate oxidase [7], laccase [8] and bilirubin oxidase (BOx) [9]. These enzymes have been demonstrated to perform ORR when immobilized on the surface of solid supports and extensively used as cathodes in biofuel cells [10-12]. The electrons necessary for ORR are transferred from the electrode to the enzyme directly without the utilization of electron carriers, such as mediators [13-16].

\footnotetext{
* Corresponding author at: Department of Chemical and Biological Engineering, Center for Micro-Engineered Materials (CMEM), University of New Mexico, 1 University of New Mexico, MSC01 1120, Albuquerque, NM 87131, USA.

E-mail address: plamen@unm.edu (P. Atanassov).

1 The two authors have contributed equally at the work.
}

Particularly for the cathode, it has been shown that BOx has a higher ORR kinetic and durability compared to laccase and ascorbate oxidase [17].

Indeed, new concept of biological/enzymatic based electrocatalyst are actually developed because it has been previously reported that traditional inorganic ORR electrocatalyst based on carbonaceous materials [18-19], platinum [20-21] and non-platinum [22-23] group metals have very low activity toward ORR at neutral $\mathrm{pH}$ [23-24]. At contrary, high electrocatalytic activity in oxygen reduction at neutral $\mathrm{pH}$ has been demonstrate multiple times for MCOs [25-29]. Differences between Pt and BOx electrochemical activity have been previously shown $[30,31,32]$. In fact, at pH 7.2-7.3, BOx catalyst demonstrated higher open circuit potential (OCP) compared to platinum $(\sim 200 \mathrm{mV})$, due to the lower activation losses of the enzymatically catalyzed ORR, and generated much higher current densities than Pt, up to $500 \mu \mathrm{A} \mathrm{cm}^{-2}$ at $0 \mathrm{mV}$ vs $\mathrm{Ag} / \mathrm{AgCl}[30]$.

The research on the use of enzymes as electrode components has generally focused on and limited to enzymatic fuel cells [33-34], where enzymes have been utilized at both the anode and cathode [35]. BOx-based enzymatic electrodes for applications in biofuel cells have been also deeply studied recently [36-40]. Enzymatic catalysis has been also explored in the design of biosensors due to the specific selectivity of the selected enzyme [41-43]. Lately, enzymatic cathodes have been utilized successfully in microbial fuel cells (MFCs), designing a hybrid biofuel cell with a microbial anode and enzymatic cathode [30, 44-46]. Schaetzle et al. [44] used a laccase cathode in a double chamber 
MFC configuration, generating high power densities. Higgins et al. [45] separated the anodic and cathodic chambers with a solid polymeric membrane in their hybrid biofuel cell, with Shewanella oneidensis MR1 at the anode and laccase at the cathode achieving a maximum power density of roughly $200 \mu \mathrm{Wcm}^{-2}\left(25 \mathrm{Wm}^{-3}\right)$ [45]. Bilirubin oxidase based cathode was also used in a hybrid biological/enzymatic fuel cell, with encapsulated S. oneidensis MR-1 at the anode, in order to increase the current output for powering marine sensors [46]. In that case, the hybrid fuel cell was working in marine environment [46]. At last, a single chamber membraneless MFC in a hybrid configuration with microbial mixed culture at the anode and bilirubin oxidase at the cathode was demonstrated [30], where both anode and the cathode were exposed to the same solution [30]. Despite the high output achieved, all of the above studies lack a durability tests that remained limited in hours/days frame time and consequently need to be addressed and reported.

Despite the superb efficiency toward ORR in neutral environment few doubts concerning applicability for long terms operational period can be raised. In fact, enzymes are subject to natural degradation over time [47], moreover, the exposition to various inorganic and organic soluble pollutants and solid matters (abiotic particles and mixed culture bacteria) can further decrease the activity of the enzymes. Usually enzyme activity on electrodes is studied in a short period of time identified in hours or few days during which the maximum activity is expressed and measured [12-17,25-30]. To the best of our knowledge, durability studies in continuous mode (more than 7 days) using MCO enzymes are missing in the current literature. Additionally, enzyme activity is mainly tested in buffer solutions [47-48], where no pollutants or suspended solids with abiotic or biotic nature has been present.

In order to evaluate the activity of BOx in a complex industrial media, in this work, the performance of a gas-diffusion bilirubin oxidase based cathode was tested continuously over time as a single electrode in two different electrolytes. Current generation of the BOx cathode was monitored in phosphate buffer saline (PBS) solution, which is the most popular electrolyte in biofuel cells and in PBS with the addition of activated sludge (PBS + AS). AS was specifically selected due to the simultaneous presence of dissolved contaminants, solid non-biological particles (suspended solids ( $1 \mu \mathrm{m}$ to $1 \mathrm{~cm}$ ), colloids ( $10 \mathrm{~nm}$ to $1 \mu \mathrm{m})$ ) and mixed consortium of various types of bacteria. Moreover, the presence of AS could simulate working conditions of MFCs systems for wastewater purification. In order to separate the effects specifically due to bacteria, solid particles and dissolved inorganic pollutants, additional experiments were run with: $\mathrm{i}$ ) an autoclaved AS + PBS (no active bacteria); ii) autoclaved AS + PBS with an enzyme encapsulated in silica-gel matrix as a physical barrier for contact with solid particles; and iii) mixed culture bacteria, "washed out" from AS, in PBS

\section{Materials and methodology}

\subsection{Cathode preparation}

A bilirubin oxidase-based cathode was prepared as previously described [10]. Briefly, carbon cloth wet proof (30 wt.\% PTFE, Fuel Cell Earth) was used as current collector and teflonized carbon black (loading $60 \mathrm{mg} \mathrm{cm}^{-2}$, Vulcan XR 72 with 35\% PTFE), referred as XC35, was hydraulically pressed on it (500 psi) and playing the role of gasdiffusion layer (GDL). Isopropanol (loading $40 \mu \mathrm{cm}^{-2}$ ) was then added to insert a hydrophobic/hydrophilic gradient from the outside of the GDL to the internal side facing the catalytic layer. On the inner side of the GDL, a multi-walled carbon nanotube paper (MWBP, Buckeye Composite) was placed and all together was pressed at 500 psi for $5 \mathrm{~min}$. Bilirubin oxidase from Myrothecium verrucaria in quantity of $10 \mathrm{mg}$ was dissolved in $1 \mathrm{ml}$ of PBS ( $50 \mathrm{mM}, \mathrm{pH} 7.5)$, then deposited on the MWBP and left over night (at least $16 \mathrm{~h}$ ) at $4{ }^{\circ} \mathrm{C}$ to allow the enzyme immobilization [10]. Additionally, in the specified case, bilirubin oxidase cathode has been also immobilized using silica encapsulation technique in order to form a physical barrier for avoiding direct contact with solids [46]. The cathode geometric area, exposed to the solution, was $2.25 \mathrm{~cm}^{2}$.

A control abiotic cathode has been prepared following the same protocol without the last step involving the enzyme addition and immobilization.

\subsection{Cell configurations and test conditions}

Single chamber glass MFC was modified with a lateral hole where the cathode was screwed (Fig. 1) [49]. The chamber was filled with $100 \mathrm{ml}$ of different electrolytes. The solutions were made of: i) $50 \mathrm{mM}$ phosphate buffer saline (PBS) solution, pH 7.5 (Fig. 1.a); ii) activated sludge (AS, $50 \mathrm{ml}$ ) and $50 \mathrm{ml}$ of $50 \mathrm{mM}$ PBS, pH 7.5 (named as $\mathrm{PBS}+\mathrm{AS})$ (Fig. 1.b); iii) autoclaved activated sludge (P, $50 \mathrm{ml})$ and $50 \mathrm{ml} \mathrm{PBS}, \mathrm{pH} 7.5$ (named as PBS + P) (Fig. 1.c); and iv) washed bacteria and suspended solids from $50 \mathrm{ml}$ of activated sludge (B) and $50 \mathrm{ml} \mathrm{PBS}$, pH 7.5 (named as PBS + B) (Fig. 1.d).

In order to discriminate the effect of dissolved pollutants from the effect of the solid non-biological particles, the cathodes have been encapsulated with a protective layer of silica to avoid the direct contact and interaction of solid particles with the enzyme. It has been shown previously that the silica layer is permeable to soluble compounds [46] and thus allowing studying the influence of the pollutants dissolved in the electrolyte.

Bacteria were collected from the AS by a centrifugation at $10,000 \mathrm{rpm}$ for $10 \mathrm{~min}$ of $50 \mathrm{ml}$ of activated sludge. The supernatant has been removed and PBS has been added. This procedure has been repeated 3 times in order to wash the bacteria from possible soluble pollutants.

In all cases, PBS contained $0.1 \mathrm{M} \mathrm{KCl}$ for increasing the conductivity. All the resulting solutions had similar $\mathrm{pH}$ corresponding to $7.5 \pm 0.15$ and remained similar during the experimental time.

\subsection{Electrochemical measurements}

The electrochemical measurements were performed in three stages: i) $1 \mathrm{~h}$ in open circuit potential (OCP); ii) linear sweep voltammetry from the $\mathrm{OCP}$ to $0 \mathrm{mV}$ (vs Ag/AgCl) at $0.2 \mathrm{mV} \mathrm{s}^{-1}$ scan rate [49]; and iii) $22.5 \mathrm{~h}$ of chronoamperometry at $300 \mathrm{mV}$ (vs. $\mathrm{Ag} / \mathrm{AgCl}$ ). All measurements were done using a potentiostat (Gamry 300). Three-electrode configuration was used for the electrochemical tests, as shown in Fig. 1 [50]. Platinum net, with comparable surface area to the working electrode, was used as counter electrode [49]. Saturated $\mathrm{Ag} / \mathrm{AgCl}$ was used as the reference electrode and the $\mathrm{BOx}$ cathode was used as the working electrode. A homemade Luggin capillary was used to reduce the ohmic resistance [49].

\subsection{Water analysis}

For the elemental composition analysis, water samples were firstly homogenized and then filtered using $0.45 \mu \mathrm{m}$ filter. For ICP-OES analysis, the samples were acidified using Ultra High Purity nitric acid (UHP $\mathrm{HNO}_{3}$ ) by adding 2 drops for $100 \mathrm{~mL}$ sample. The samples were diluted to acceptable range within the calibration standards using $2 \%$ nitric acid. Samples were transferred into ICP-OES autosampler tubes and then placed for the auto sampler setup. The instrument optics was optimized using $\mathrm{Hg}$ and $\mathrm{Mn}$ view alignment for the wavelengths. The system was then calibrated using a blank and three point calibration standards diluted sequentially. Samples were then analyzed after the calibration curve was validated using QC check solutions. The data obtained were then validated, verified, and exported.

For the ions analysis, samples were analyzed using Ion Chromatography (IC). None acidified filtered samples $(0.45 \mu \mathrm{m}$ filter) were used in this analysis. The samples were diluted to acceptable range within the calibration standards using $18 \mathrm{M} \Omega$ water. Samples were then 

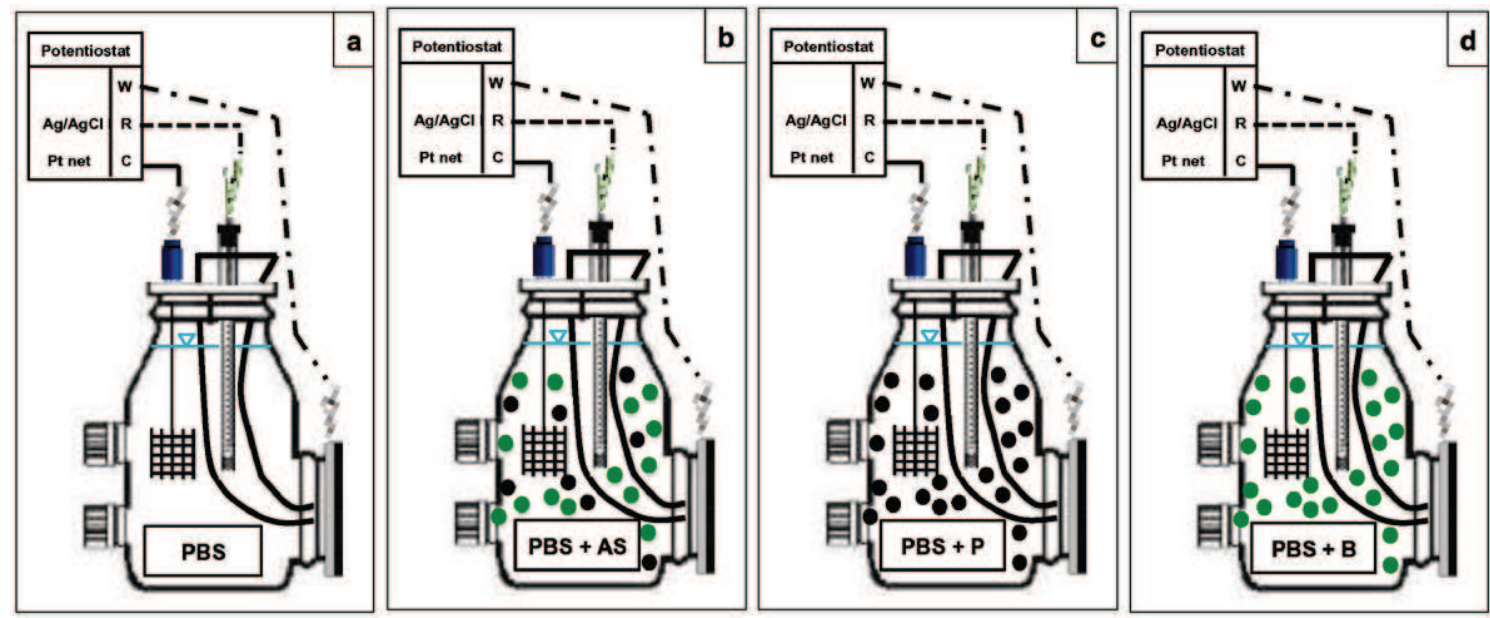

Fig. 1. Cell configuration, with the details of the four different electrolytes tested: a) PBS, b) PBS and activated sludge (50/50 mixture), c) PBS and autoclaved activated sludge (50/50 mixture) with only pollutants (P) and d) PBS and "washed" bacteria.

transferred into IC autosampler tubes and placed in their locations for the auto sampler setup. The system was then calibrated using a blank and three point calibration standards diluted sequentially. Samples were then analyzed after the calibration curve was validated using QC check solutions. The data obtained were then validated, verified, and exported.

\section{Results and discussion}

\subsection{BOx electrochemical response in PBS solution}

The continuous operation of the BOx-based gas-diffusion cathode was first studied in PBS ( $\mathrm{pH}$ 7.5), as a reference test with the goal of evaluating the operation of this cathode in the absence of interferences from soluble pollutants, bacteria and suspended solids. Fig. 2.a shows the current densities generated by the cathode over 45 days of a constant polarization at $300 \mathrm{mV}$ vs. $\mathrm{Ag} / \mathrm{AgCl}$. A continuous decrease in the current produced by BOx-cathode was recorded over time. The current density/time dependence can be separated into three different successive regions based on the rate of current decrease that can be considered linear for each distinct region. Region I comprises the first three days of operation where a sharp decrease in the generated current was observed. The current density decreased at a rate of approximately $60 \mu \mathrm{Acm}^{-2} \mathrm{day}^{-1}$, starting from a value of $\sim 350 \mu \mathrm{Acm}^{-2}$, and decreasing to $\sim 175 \mu \mathrm{Acm}^{-2}$ during this initial period. The second region (Region II) includes the performance from days 3 to 9, when an average current decay of $\sim 10 \mu \mathrm{Acm}^{-2} \mathrm{day}^{-1}$ was detected. Region III comprised between days 9 and 45 where the decrease in the current densities was continuous with a rate of $\sim 1.5 \mu \mathrm{Acm}^{-2} \mathrm{day}^{-1}$. Similar trend was achieved by BOx cathode encapsulated with silica indicating that the silica encapsulation did not have effect on the current output performance (results not showed). A linear decrease in the current density of BOxbased bio-cathode was also observed from Mano et al. who studied the operation of wired-BOx cathode [17]. Mano et al. reported loss of around $50 \%$ of cathode activity in $20 \mathrm{mM}$ PBS (pH 7.4) with $0.15 \mathrm{M}$ $\mathrm{NaCl}$, at $37.5^{\circ} \mathrm{C}$, in 6 days, which was similar to the current decrease observed in this study [17].

To study the cathode degradation, potentiodynamic polarization curves were carried out each day after $1 \mathrm{~h}$ at open circuit conditions. Fig. 2.b shows polarization curves at selected days, representing the three regions with different rates of current decrease. Particularly, it can be noticed that while the OCP decreased slowly, the limiting current instead had a fast drop, especially in the initial days, stabilizing over time.
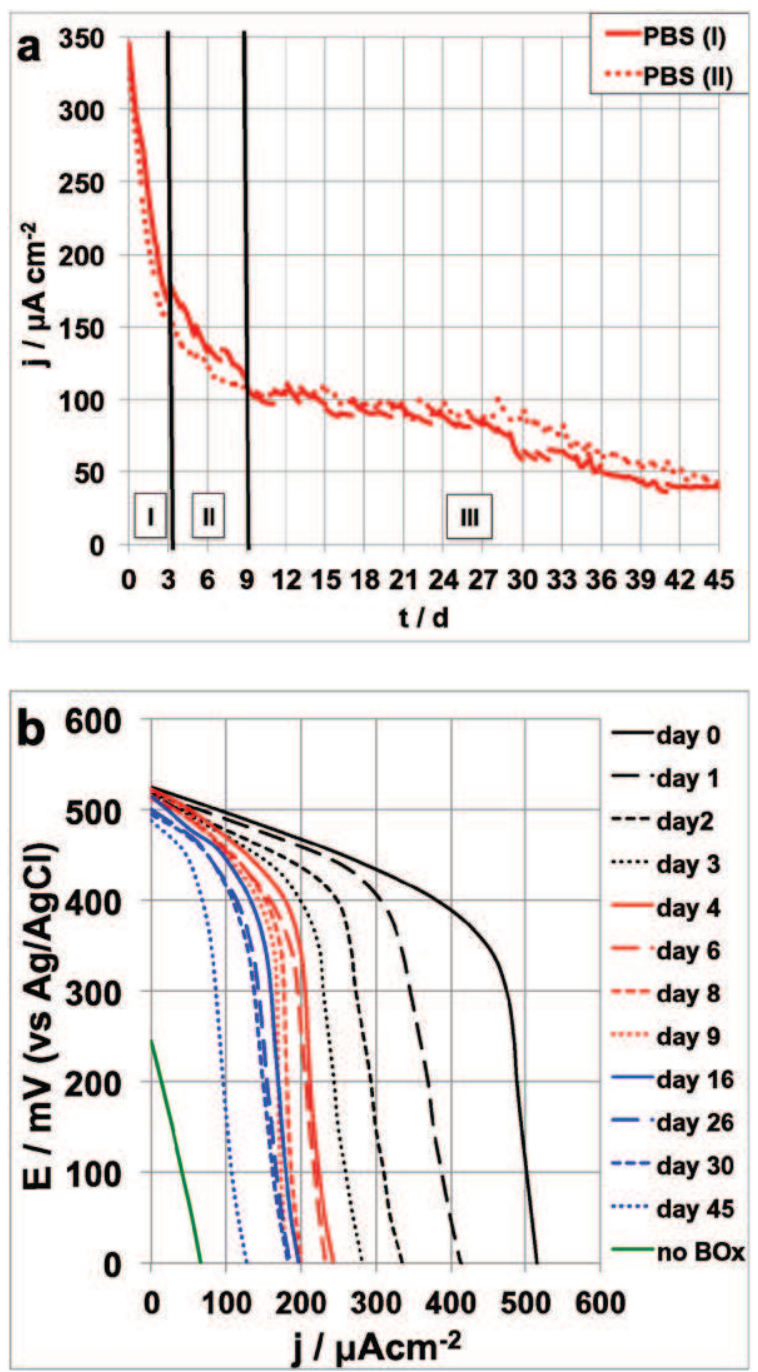

Fig. 2. Long-term operation of BOx cathode over 45 days when polarized with constant potential of $300 \mathrm{mV}$ vs. $\mathrm{Ag} / \mathrm{AgCl}$ using PBS as electrolyte (two replicates) (a) and representative potentiodynamic polarization curves of the BOx cathode in PBS, taken each day of MFC operation (b). Green line indicates cathode without BOx. 
No cathodic current has been generated at $300 \mathrm{mV} v$ s. $\mathrm{Ag} / \mathrm{AgCl}$ in absence of BOx (control abiotic cathode). The OCP of the control electrode appeared to be $246 \mathrm{mV}$ vs. $\mathrm{Ag} / \mathrm{AgCl}$ therefore ORR on this electrode at potentials higher than OCP could not be performed. It has to be noted that the OCP of the BOx containing cathode has never reached the OCP of the control electrode ( $475 \mathrm{mV}$ vs $\mathrm{Ag} / \mathrm{AgCl}$ ) indicating (residual or partial) BOx activity along the 45 days of operation. Singh et al. measured the electrocatalytic activity of adsorbed BOx along with the stiffness of the protein layer and concluded that structural rearrangements and water loss are the primary culprits in activity loss in these cathodes. It was also established that this effect is not a result of enzyme attachment but rather to the applied potential [47]. The latter can explain the fast current drop during the initial stages of the cathode operation.

\subsection{BOx electrochemical response in $P B S+A S$}

Continuous operational analysis has been also carried out introducing $50 \%$ of activated sludge, naturally containing pollutants, suspended solid matters and mixed culture of bacteria. This aspect is important for examining the effect of additional abiotic and biotic matters on the long-term operation of the BOx cathode. The same polarization set of experiments was carried out using the configuration shown in Fig. 1b.

The decrease in performance of the BOx cathode exposed to the activated sludge followed the same general trend as observed for the BOx cathode in clean PBS, but the current densities generated in presence of activated sludge were significantly lower (Fig. 3.a) indicating an immediate inhibition of the enzyme. In fact, at day 3, the operational characteristics of the cathode immersed in the PBS + AS electrolyte were already similar to the operational characteristics of the same cathode exposed only to PBS for 45 days. In the presence of AS, the first current drop was almost linear until day 3 with a rate of approximately $65 \mu \mathrm{A} \mathrm{cm}^{-2}$ day $^{-1}$ similar to the one determined for BOx in PBS but with a different starting current. The initial current (day 0 ) was roughly $100 \mu \mathrm{A} \mathrm{cm}^{-2}$ lower suggesting an instantaneous degradation/inhibition of the enzyme or enzyme pollution by a polluting layer of adsorbed lowmolecular weight soluble contaminants limiting $\mathrm{O}_{2}$ transport to the active site of the BOx. From day 3 to day 45, the current drop was much lower and could be linearized with a current decreased estimated in $1.4 \mu \mathrm{A} \mathrm{cm}{ }^{-2}$ similar to the decrease measured in PBS solution from day 9 to day 45 .

\subsection{Electrochemical characterization carried out combining chronoamperometry, polarization curves and open circuit potential}

A comparison between the current recorded during the chronoamperometry study and the current generated during the potentiodynamic polarization of the electrode was carried out. Moreover, the changes in OCPs were monitored over the 45 days experiment (Fig. 4). The currents obtained during the polarization curves at $0 \mathrm{mV}$ and $300 \mathrm{mV}$ vs. $\mathrm{Ag} / \mathrm{AgCl}$ were used for the comparison. Fig. 4.a shows the behavior of the BOx cathode in PBS while Fig. 4.b shows the trend of the cathode operation in PBS + AS. As it can be seen, the current obtained from the polarization curves is always higher than the one from the chronoamperometry, despite the fact that they follow similar pattern (Fig. 4). In the case of PBS, the OCP slightly decreased over time from $520 \mathrm{mV}$ to $475 \mathrm{mV}$ (Fig. 4.a). Moreover, it can be noticed that the OCP remained above $500 \mathrm{mV}$ till day 32 . To the best of our knowledge, this high cathode potential has never been recorded for any cathode working continuously at neutral conditions for 45 days. The high OCP value can be explained by the preserved BOx activity along the 45 days (Fig. 4.a). At the same time the BOx cathode in AS solution had initially high OCP close to $500 \mathrm{mV}$ but the value dropped constantly until reaching $375 \mathrm{mV}$ at day 45 (Fig. 4.b). Looking at the shape of the polarization curves (Figs. 2.b and 3.b) and the potential at which the diffusional limitation starts, it can be concluded that the gas-diffusion layer of the cathodes does not change over time. In fact, the slope of $\mathrm{I} / \mathrm{E}$ is
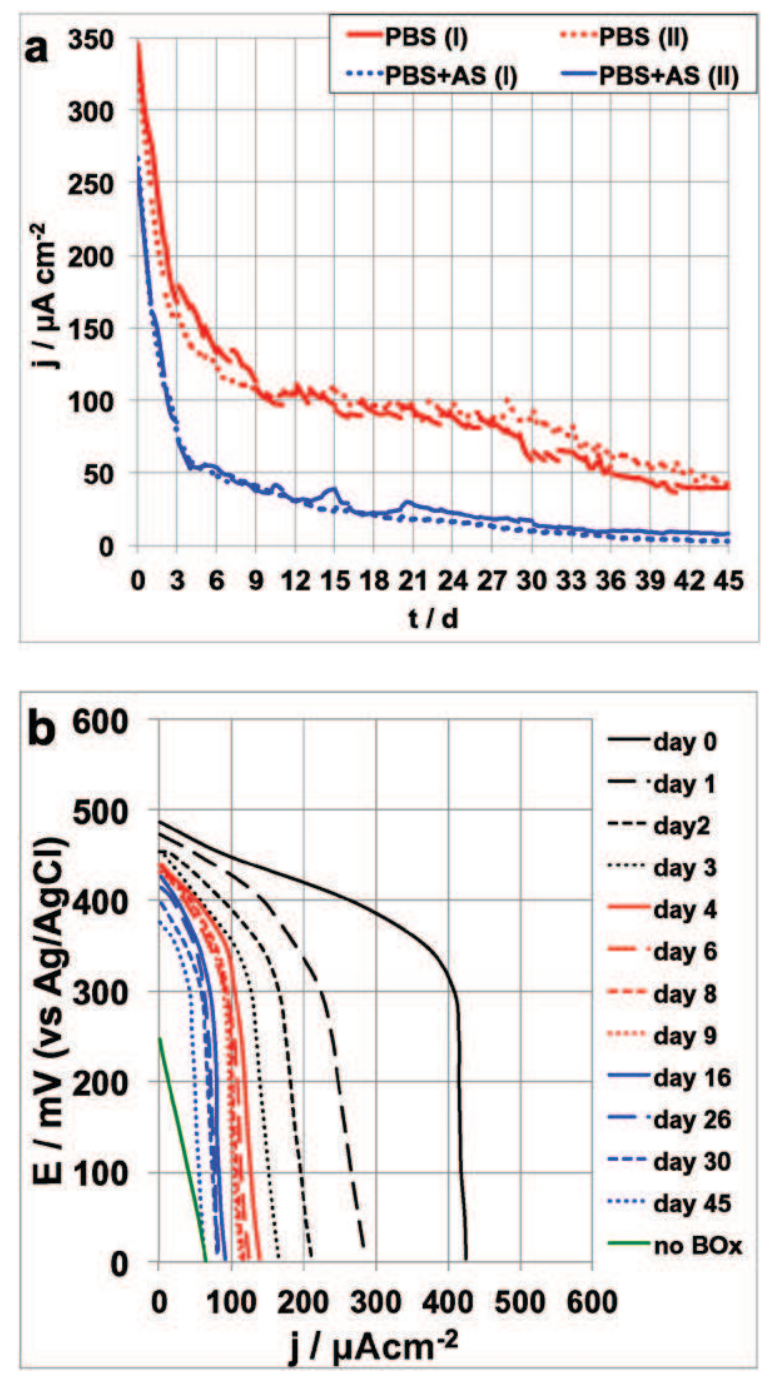

Fig. 3. Long-term operation of BOx cathode over 45 days when polarized with constant potential of $300 \mathrm{mV}$ vs. $\mathrm{Ag} / \mathrm{AgCl}$ using PBS and activated sludge (AS) as electrolyte (two replicates), with comparison to PBS-only runs (a). Representative potentiodynamic polarization curves of the BOx cathode in PBS + AS (b). Green line indicates cathode without BOx.

decreasing in Figs. 2.b and 3.b confirming that is the catalyst, mainly quantity and activity, responsible for this phenomenon. In other words, it is not a problem of mass transfer (like oxygen diffusion through the GDL or at the gas/liquid/solid interface) because the first part of the curves between OCP and $300 \mathrm{mV} / \mathrm{AgAgCl}$ are the one changing over time. In addition, it has to be pointed out that the OCP of the enzymatic cathodes never reached the low value OCP of the abiotic control electrode, which is another indication of enzyme activity along the course of the experiment.

Since the OCP indicates the existence of active enzyme and enzymatically catalyzed ORR and at the same time the current obtained from the polarization curves show preserved structure of the GDL, we can assume that the observed decrease in the cathode performance over time (Fig. 4) is due to a decreasing quantity of active enzyme units, which decrease occurs with much faster rate in presence of AS. The decrease of the cathode enzyme quantity/activity regardless of the solution can be explained by: i) enzyme natural deactivation; ii) leaching or release of enzyme from the surface to the bulk (non-covalent immobilization); iii) $\mathrm{H}_{2} \mathrm{O}$ accumulation that stops the gaseous oxygen (substrate accessibility). Our results indicate strong and fast inhibition effect of the activated sludge content on the enzymatic activity. In 


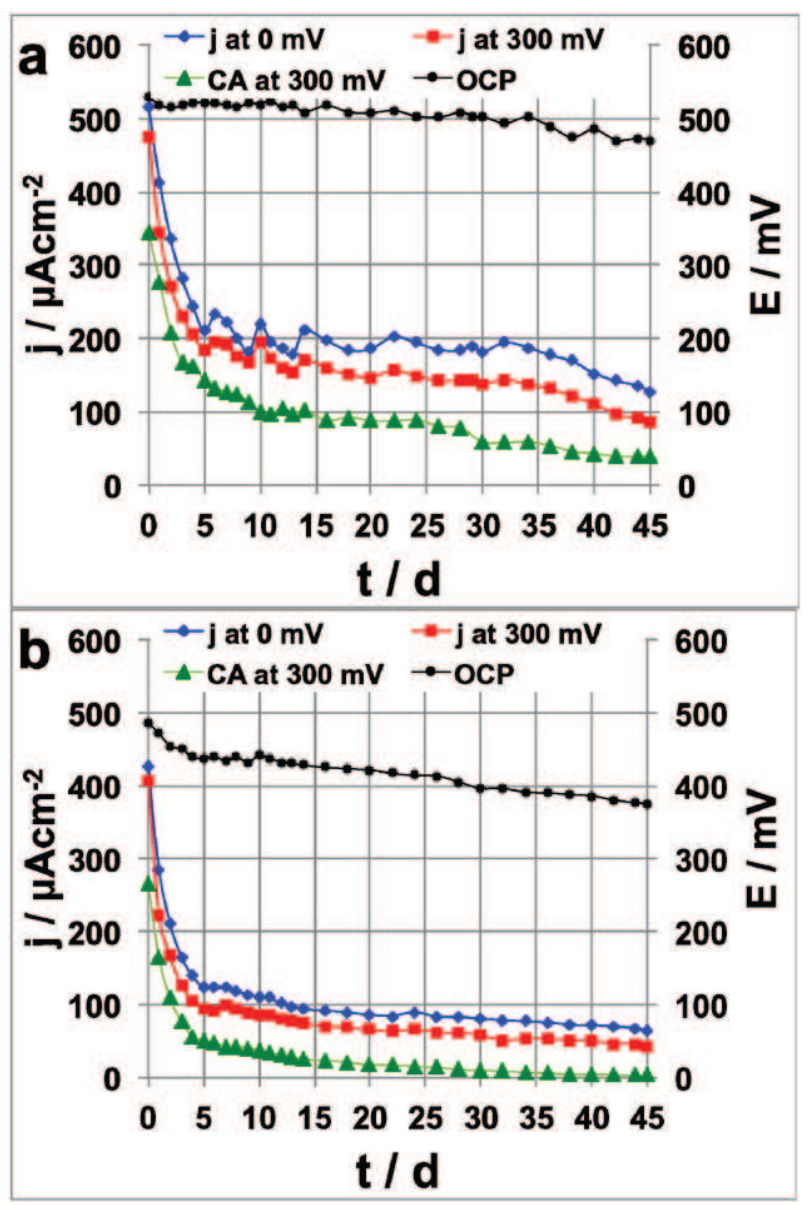

Fig. 4. OCP, current from the chronoamperometry at $300 \mathrm{mV}$ vs. $\mathrm{Ag} / \mathrm{AgCl}$ and current from the polarization curves at $300 \mathrm{mV}$ and $0 \mathrm{mV}$ for the BOx cathode in PBS (a) and PBS + AS (b).

presence of AS, the additional possibilities for decayed cathode performance are i) enzyme deactivation by soluble inhibitors and ii) indirect deactivation of enzyme by bacterial attachment on electrode surface. The presence of a variety of compounds in the AS (especially oxidizable compounds) can cause mixed potential at the cathode, which apparently leds to a decrease in the OCP of the electrode over time. Also, the variation of $\mathrm{pH}$ toward alkaline values could impact negatively the OCP but, as mentioned before, the $\mathrm{pH}$ of the bulk remained constant along the duration of the experiment not ensuring that the local $\mathrm{pH}$ at the electrode surface is not different if microorganisms colonized the surface [51-52]. The ОСР values may be considered as a good indicator of enzyme activity and long-term electrode operation.

3.4. BOx electrochemical response as a function of pollutants, solids and bacteria presence

Activated sludge is a complex matrix, which contains not only dissolved organic and inorganic compounds but also bacteria and solid non-biological particles. In order to discriminate the effects of the dissolved compounds in the AS from those of suspended solids and bacteria, three additional experiments were performed (Fig. 5). The first experiment used autoclaved activated sludge mixed with PBS as electrolyte to eliminate the effects of the bacterial activity and study the influence of both, the soluble pollutants and the solid particles in the sludge (named as PBS + P). The second experiment used, BOx enzyme encapsulated in a silica gel matrix on the electrode surface. This test was conducted in PBS + AS (named as PBS + P encaps). The silica gel plays the role of a physical barrier and prevents the interaction of the enzyme

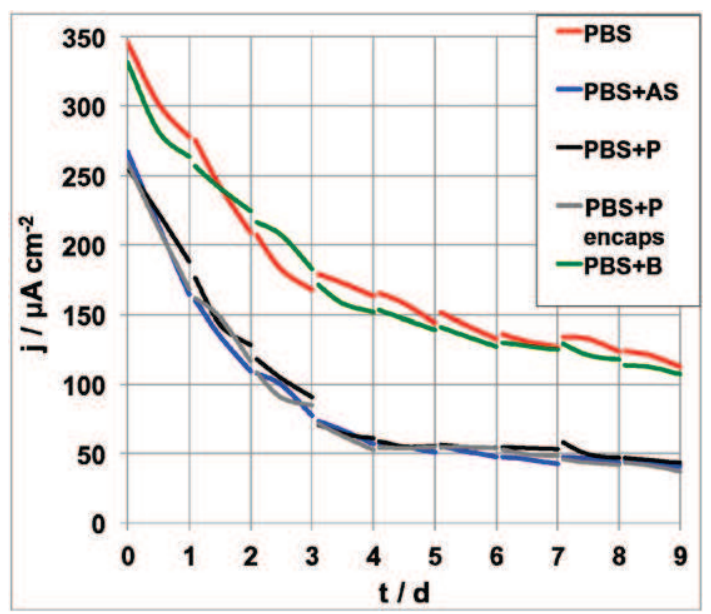

Fig. 5. BOx cathode performance (current density) over 9 days when polarized with constant potential of $0.3 \mathrm{~V}$ vs. $\mathrm{Ag} / \mathrm{AgCl}$ using PBS (red), $\mathrm{PBS}+\mathrm{AS}$ (blue), $\mathrm{PBS}+\mathrm{P}$ (pollutants, black), PBS + P with encapsulated BOx cathode (gray) and PBS + B ("washed" bacteria, green) as electrolyte. Only one replicate is shown in the figure.

with the solid particles and bacteria present in the AS and allows the soluble pollutants to penetrate the silica matrix and interact with the enzyme. Thus only the contribution of soluble pollutants can be studied. Encapsulation of biological specimens in silica matrix has been demonstrated to prolong the activity of the biological species and at the same time allows the penetration of water and ions [10]. The third experiment used a re-suspension of mixed culture bacteria and solid particles in a phosphate buffer (named as PBS $+\mathrm{B}$ ). The latter allows monitoring the influence of bacteria on the cathode performance.

The current generated by the BOx cathode in activated sludge $(\mathrm{PBS}+\mathrm{AS})$ and autoclaved activated sludge with inactivated bacteria $($ PBS + P) was identical. Furthermore, the utilization of silica encapsulation (PBS + P encaps) for protecting the enzyme from a direct contact with the solid particles and bacteria did not change the current output that resulted similar to PBS + AS and PBS + P. This indicates that the presence of bacteria along with the solid particles in the electrolyte did not have a negative effect on the cathodes activity and the reason for the decreasing over time performance of the enzymatic electrodes was more probably due to soluble pollutants present in the AS.

The decay of current densities over time for the BOx cathode exposed only to PBS and to bacteria in presence of suspended solids $(\mathrm{PBS}+\mathrm{B})$ were also similar but higher than the rest of the experiments carried out (Fig. 5). The latter confirmed that neither bacteria nor the present solid particles in the AS negatively affected the current output of the BOx cathode. The reduction in the overall enzyme activity by the autoclaved activated sludge occurred at virtually the same rate as by live activated sludge as a result of the dissolved pollutants in both.

Analysis of the autoclaved activated sludge + PBS solution were carried out to determine the elemental and ion content (Table 1).

As expected, many different moieties were identified in the PBS + AS solution (Table 1). High concentrations of phosphate, potassium and chloride were due to the PBS $+\mathrm{KCl}$ solution added. Other detected anions were contributed by the activated sludge, including nitrate, sulfate and fluoride (Table 1). The presence of sulfate in an activated sludge has been previously reported [53-56], and it was suggested to be one reason for the deactivation of platinum cathodes utilized in MFC for wastewater treatment and electricity production [55-56]. It is also well known that the presence of halogens impacts the activity of multicopper oxidases [17]. The negative effect of halogens is far more pronounced when laccase is used [17]. The order of inhibitory effect of halogens on the enzymatic cathode has been found to be the following: $\mathrm{F}^{-}>\mathrm{Cl}^{-}>\mathrm{Br}^{-}$[17]. Fluoride anion was reported to 
Table 1

Anions and cations in autoclaved activated sludge with PBS.

\begin{tabular}{|c|c|c|c|c|c|c|c|}
\hline Anions & $\mathrm{mg} \mathrm{l}^{-1}$ & Cations & $\mathrm{mg} \mathrm{l}^{-1}$ & Cations & $\mathrm{mg} \mathrm{l}^{-1}$ & Cations & $\mathrm{mg} \mathrm{l}^{-1}$ \\
\hline Nitrate & 53.7 & Aluminum & 2.4 & Iron & 20.05 & Nickel & 0.14 \\
\hline Nitrite & Not detected & Boro & 2 & Lithium & 0.05 & Silicon & 8.4 \\
\hline Sulfate & 67.5 & Barium & 0.29 & Magnesium & 1.35 & Strontium & 0.17 \\
\hline Bromide & Not detected & Calcium & 10.8 & Manganese & 0.1 & Vanadium & 0.02 \\
\hline \multirow[t]{2}{*}{ Fluorine } & 15.8 & Chromium & 0.05 & Molybdenum & 0.01 & Zinc & 1.35 \\
\hline & & Copper & 0.32 & Sodium & 126.5 & & \\
\hline
\end{tabular}

completely inhibit laccase activity, while the inhibition effect of chloride was less pronounced [17]. It has been widely discussed that the strong inhibition effect of $\mathrm{F}^{-}$is due to attachment of this anion to the T2/T3 center, blocking the internal electron transfer from the T1 center to the TNC $[17,57-58]$. It was suggested that contrary to fluoride, $\mathrm{Cl}^{-}$ binds to the $\mathrm{T} 1$ center blocking the access to the substrate-binding pocket and suppressing electron transfer carried out through the utilization of mediators, but when direct electron transfer occurs, the influence of the chloride is small. Negligible influence of $\mathrm{Cl}^{-}$in the range of $0-1 \mathrm{M}$ on the activity of BOx was demonstrated by Mano et al. [17]. The concentration of $\mathrm{Cl}^{-}$added in the electrolyte in our experiment was $0.1 \mathrm{M}$, proposing that the $\mathrm{Cl}^{-}$most likely is not the ion decreasing the cathodes output. Mano et al. also observed that $0.5 \mathrm{M}$ fluoride addition decreased the current density of BOx cathode about 30\%, and about $90 \%$ was lost at fluoride concentrations above $1 \mathrm{M}$ [17]. The concentration of $\mathrm{F}^{-}$in AS used in the current study was determined to be $0.9 \mathrm{M}$. This concentration could impose huge negative effect on the BOx activity as previously demonstrated [17]. Recently, it has been shown that also hydrogen peroxide has a negative influence on the BOx performance [59-60]. Detailed investigation needs to be done to study the effect of each pollutant on the activity of BOx and the designed enzymatic cathode.

At the end of the experiments, macroscopic images of the cathode surfaces exposed to the electrolyte were taken (Fig. 6). As expected, no biofilm formation was detected on the BOx cathode exposed to PBS for 45 days (Fig. 6.a) and to the autoclaved AS for 9 days (Fig. 6.d). In fact in both cases, the color remained black as for the origin cathode. Biofilms clearly had developed after 45 days in contact with the electrolyte containing active AS (Fig. 6.b) and also after 9 days on the BOx cathode in contact with resting bacterial cells and suspended solids (Fig. 6.c). Despite all these macroscopic deposits, there were no phenomena of transport limitations observed as indicated by the polarization curves

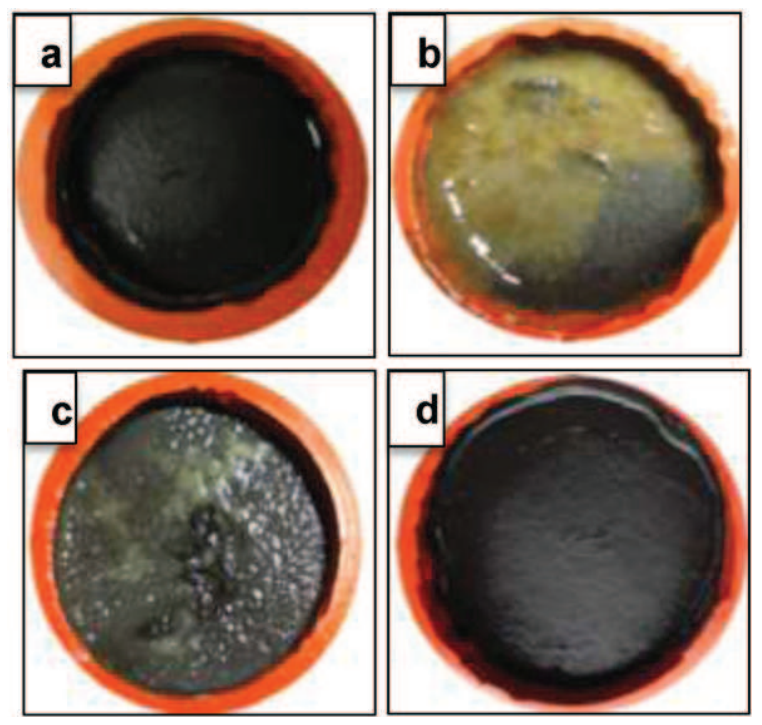

Fig. 6. Images of the cathodes after 45 days of constant operation in PBS (a) and in PBS + AS (b); and after 9 days of operation in presence of bacteria (PBS + bacteria) (c) and global pollutants (PBS + autoclaved AS) (d). carried out and as we already discusses, no negative effect was occurring due to the presence of bacteria and solid particles.

\section{Conclusion}

Continuous operation of bilirubin oxidase cathode was investigated by placing the cathode in "clean" conditions and exposed to activated sludge. The cathodes in PBS only and in PBS supplemented with mixed culture of bacteria demonstrated higher performance than the cathodes in contact with soluble pollutants, naturally present in the activated sludge. OCP higher than $500 \mathrm{mV}$ vs. $\mathrm{Ag} / \mathrm{AgCl}$ over 32 days have been observed. The results demonstrated that the lost in the enzyme catalytic activity was due to the presence of dissolved inhibitors. Biofilm formation on the cathode and the presence of suspended particles did not affect the ORR rate. Generally, the OCP of the BOx cathode was a very significant parameter, and it may be used as an indicator of the enzyme activity.

\section{Acknowledgments}

This work was supported by the US Army Research Office (Award W911NF-12-1-0208) and by the UNM Center for Emerging Energy Technologies. C.S was supported in part by the Electrochemical Society F.M. Becket Summer Fellowship 2013. This project was also partially supported by the Electrochemical Society and Bill \& Melinda Gates Foundation under initiative: "Applying Electrochemistry to Complex Global Challenges".

\section{References}

[1] N.U. Nair, C.A. Denard, H. Zhao, Engineering of enzymes for selective catalysis, Curr. Org. Chem. 14 (2010) 1870-1882.

[2] http://www.enzyme-database.org/downloads/ec1.pdf

[3] C.H. Kjaergaard, J. Rossmeisl, J.K. Nørskov, Enzymatic versus inorganic oxygen reduction catalysts: comparison of the energy levels in a free-energy scheme, Inorg. Chem. 49 (8) (2010) 3567-3572.

[4] S. Calabrese Barton, J. Gallaway, P. Atanassov, Enzymatic biofuel cells for implantable and microscale devices, Chem. Rev. 104 (10) (2004) 4867-4886.

[5] B. Erable, D. Feron, A. Bergel, Microbial catalysis of the oxygen reduction reaction for microbial fuel cells: a review, ChemSusChem 5 (2012) 975-987.

[6] E.I. Solomon, U.M. Sundaram, T.E. Machonkin, Multicopper Oxidases and Oxygenases, Chem. Rev. 96 (1996) 2563-2605.

[7] A. Messerschmidt, R. Ladenstein, R. Huber, M. Bolognesi, L. Avigliano, R. Petruzzelli, A. Rossi, A. Finazzi-Agró, Refined crystal structure of ascorbate oxidase at $1.9 \mathrm{~A}$ resolution, J. Mol. Biol. 224 (1) (1992) 179-205.

[8] I. Zaitseva, V. Zaitsev, G. Card, K. Moshkov, B. Bax, A. Ralph, P. Lindley, The X-ray structure of human serum ceruloplasmin at 3.1A: nature of the copper centres, J. Biol. Inorg. Chem. (1) (1996) 15-23.

[9] J. Vivekananthan, R.A. Rincón, V. Kuznetsov, S. Pöller, W. Schuhmann, Biofuel-cell cathodes based on bilirubin oxidase immobilized through organic linkers on 3D hierarchically structured carbon electrodes, Chem. Electroanal. Chem 1 (11) (2014) 1901-1908.

[10] S. Babanova, K. Artyushkova, Y. Ulyanova, S. Singhal, P. Atanassov, Design of experiments and principal component analysis as approaches for enhancing performance of gas-diffusional air-breathing bilirubin oxidase cathode, J. Power Sources 245 (2014) 389-397.

[11] A. Habrioux, K. Servat, S. Tingry, K.B. Kokoh, Enhancement of the performances of a single concentric glucose $/ \mathrm{O}_{2}$ biofuel cell by combination of bilirubin oxidase/Nafion cathode and Au-Pt anode, Electrochem. Commun. 11 (1) (2009) 111-113.

[12] R. Kontani, S. Tsujimura, K. Kano, Air diffusion biocathode with CueO as electrocatalys adsorbed on carbon particle-modified electrodes, Bioelectrochemistry 76 (2009) $10-13$.

[13] M.S. Thorum, C.A. Anderson, J.J. Hatch, A.S. Campbell, N.M. Marshall, S.C. Zimmerman, Y. Lu, A.A. Gewirth, Direct, electrocatalytic oxygen reduction by laccase 
on anthracene-2-methanethiol modified gold, J. Phys. Chem. Lett. 1 (15) (2010) 2251-2254.

[14] K. Murata, K. Kajiya, N. Nakamura, H. Ohnoa, Direct electrochemistry of bilirubin oxidase on three-dimensional gold nanoparticle electrodes and its application in a biofuel cell, Energy Environ. Sci. 2 (2009) 1280-1285.

[15] F. Giroud, S.D. Minteer, Anthracene-modified pyrenes immobilized on carbon nanotubes for direct electroreduction of $\mathrm{O}_{2}$ by laccase, Electrochem. Commun. 34 (2013) 157-160.

[16] U. Salaj-Kosla, S. Pöller, Y. Beyl, M.D. Scanlon, S. Beloshapkin, S. Shleev, W. Schuhmann, E. Magner, Direct electron transfer of bilirubin oxidase (Myrothecium verrucaria) at an unmodified nanoporous gold biocathode, Electrochem. Commun. 16 (1) (2012) 92-95

[17] N. Mano, H. Kim, Y. Zhang, A. Heller, An oxygen cathode operating in a physiological solution, J. Am. Chem. Soc. 124 (2002) 6480-6486.

[18] C. Santoro, K. Artyushkova, S. Babanova, P. Atanassov, I. Ieropoulos, M. Grattieri, P. Cristiani, S. Trasatti, B. Li, A.J. Schuler, Parameters characterization and optmization of activated carbon (AC) cathodes for microbial fuel cell applications, Bioresour. Technol. 163 (2014) 54-63.

[19] H. Dong, H. Yu, H. Yu, N. Gao, X. Wang, Enhanced performance of activated carbonpolytetrafluoroethylene air-cathode by avoidance of sintering on catalyst layer in microbial fuel cells, J. Power Sources 232 (2013) 132-138.

[20] E. Antolini, Composite materials for polymer electrolyte membrane microbial fuel cells, Biosens. Bioelectron. 69 (2015) 54-70.

[21] X. Zhu, J.C. Tokash, Y. Hong B.E. Logan, Controlling the occurrence of power overshoot by adapting microbial fuel cells to high anode potentials, Bioelectrochemistry 90 (2013) 30-35

[22] Z. Wang, C. Cao, Y. Zheng, S. Chen, F. Zhao, Abiotic oxygen reduction reaction catalysts used in microbial fuel cells, Chem. Electroanal. Chem. 1 (2014) 1813-1821.

[23] C. Santoro, A. Serov, C.W. Narvaez Villarrubia, S. Stariha, S. Babanova, A.J. Schuler, K. Artyushkova, P. Atanassov, Double chamber MFC with non-platinum group metal Fe-N-C cathode catalyst, ChemSusChem 8 (5) (2015) 828-834.

[24] S. Brocato, A. Serov, P. Atanassov, pH dependence of catalytic activity for ORR of the non-PGM catalyst derived from heat-treated Fe-phenanthroline, Electrochim. Acta 87 (2013) 361-365.

[25] M. Grattieri, P. Scodeller, C. Adam, E.J. Calvo, Non-competitive reversible inhibition of laccase by $\mathrm{H}_{2} \mathrm{O}_{2}$ in osmium mediated layer-by-layer multilayer $\mathrm{O}_{2}$ biocathodes, J. Electrochem. Soc. 162 (9) (2015) G82-G86.

[26] L. Edembe, S. Gounel, M. Cadet, F. Durand, N. Mano, A highly efficient $\mathrm{O}_{2}$ cathode based on bilirubin oxidase from Bacillus pumilus operating in serum. Electrochem. Commun. 23 (2012) 80-82

[27] V. Climent, Y. Fu, S. Chumillas, B. Maestro, J.-F. Li, A. Kuzume, S. Keller, T. Wandlowski, Probing the electrocatalytic oxygen reduction reaction reactivity of immobilized multicopper oxidase CueO, J. Phys. Chem. C 118 (29) (2014) 15754-15765.

[28] S. Wherland, O. Farver, I. Pecht, Multicopper oxidases: intramolecular electron transfer and $\mathrm{O}_{2}$ reduction, J. Biol. Inorg. Chem. 19 (4-5) (2014) 541-554.

[29] S. Tsujimura, Y. Kamitaka, K. Kano, Diffusion-controlled oxygen reduction on multicopperoxidase-adsorbed carbon aerogel electrodes without mediator, Fuel Cells 6 (2007) 463-469.

[30] C. Santoro, S. Babanova, P. Atanassov, B. Li, I. Ieropoulos, P. Cristiani, High power generation by a membraneless single chamber microbial fuel cell (SCMFC) using enzymatic bilirubin oxidase (BOx) air-breathing cathode, J. Electrochem. Soc. 160 (10) (2013) H720-H726.

[31] V. Soukharev, N. Mano, A. Heller, A four-electron $\mathrm{O}_{2}$-electroreduction biocatalyst superior to platinum and a biofuel cell operating at $0.88 \mathrm{~V}$, J. Am. Chem. Soc. 126 (27) (2004) 8368-8369.

[32] N. Mano, J.L. Fernandez, Y. Kim, W. Shin, AJ. Bard, A. Heller, Oxygen is electroreduced to water on a "wired" enzyme electrode at a lesser overpotential than on platinum, J. Am. Chem. Soc. 125 (2003) 15290-15291.

[33] D. Leech, P. Kavanagh, W. Schuhmann, Enzymatic fuel cells: recent progress, Electrochim. Acta 84 (2012) 223-234.

[34] I. Ivanov, T. Vidaković-Koch, K. Sundmacher, Recent advances in enzymatic fuel cells: experiments and modeling, Energies 3 (2010) 803-846.

[35] S.D. Minteer, B.Y. Liaw, M.J. Cooney, Enzyme-based biofuel cells, Curr. Opin. Biotechnol. 18 (3) (2007) 228-234.

[36] E.H. Yu, K. Scott, Enzymatic biofuel cells-fabrication of enzyme electrodes, Energies 3 (2010) 23-42.
[37] S. Cosnier, M. Holzinger, A. Le Goff, Recent advances in carbon nanotube-based enzymatic fuel cells, Front. Bioeng. Biotechnol. 2 (2014) 45

[38] A. Karimi, A. Othman, A. Uzunoglu, L. Stanciu, S. Andreescu, Graphene based enzymatic bioelectrodes and biofuel cells, Nanoscale 7 (2015) 6909-6923.

[39] M. Falk, Z. Blum, S. Shleev, Direct electron transfer based enzymatic fuel cells, Electrochim. Acta 82 (2012) 191-202.

[40] V. Scherbahn, M.T. Putze, B. Dietzel, T. Heinlein, J.J. Schneider, F. Lisdat, Biofuel cells based on direct enzyme-electrode contacts using PQQ-dependent glucose dehydrogenase/bilirubin oxidase and modified carbon nanotube materials, Biosens. Bioelectron. 61 (2014) 631-638.

[41] B. Batra, S. Lata, Sunny, J.S. Rana, C.S. Pundir, Construction of an amperometric bilirubin biosensor based on covalent immobilization of bilirubin oxidase onto zirconia coated silica nanoparticles/chitosan hybrid film, Biosens. Bioelectron. 44 (2013) 64-69.

[42] G. Göbel, T. Dietz, F. Lisdat, Bienzyme sensor based on an oxygen reducing bilirubin oxidase electrode, Electroanalysis 22 (14) (2010) 1581-1585.

[43] M. Grattieri, S. Babanova, C. Santoro, E. Guerrini, S.P.M. Trasatti, P. Cristiani, M Bestetti, P. Atanassov, Enzymatic oxygen micro-sensor based on bilirubin oxidase applied to microbial fuel cells analysis, Electroanalysis 27 (2) (2015) 327-335.

[44] O. Schaetzle, F. Barriere, U. Schroder, An improved microbial fuel cell with laccase as the oxygen reduction catalyst, Energy Environ. Sci. 2 (2009) 96-99.

[45] S. Higgins, C. Lau, P. Atanassov, S. Minteer, M. Cooney, Hybrid biofuel cell: microbial fuel cell with an enzymatic air-breathing cathode, ACS Catal. 1 (2011) 994-997.

[46] G. Strack, H.R. Luckarift, S.R. Sizemore, R.K. Nichols, K.E. Farrington, P.K. Wu, P. Atanassov, J.C. Biffinger, G.R. Johnson, Power generation from a hybrid biologica fuel cell in seawater, Bioresour. Technol. 128 (2013) 222-228.

[47] K. Singh, T. McArdle, P.R. Sullivan, C.F. Blanford, Sources of activity loss in the fuel cell enzyme bilirubin oxidase, Energy Environ. Sci. 6 (2013) 2460-2464.

[48] H. Bisswanger, Enzyme assays, Perspect. Sci. 1 (1-6) (2014) 41-55.

[49] C. Santoro, S. Babanova, K. Artyushkova, J.A. Cornejo, L.K. Ista, O. Bretschger, E. Marsili, P. Atanassov, A.J. Schuler, Influence of anode surface chemistry on microbial fuel cell operation, Bioelectrochemistry 106 (2015) 141-149.

[50] M. Rimboud, D. Pocaznoi, B. Erable, A. Bergel, Electroanalysis of microbial anodes fo bioelectrochemical systems: basics, progress and perspectives, Phys. Chem. Chem. Phys. 16 (31) (2014) 16349-16366.

[51] S.C. Popat, D. Ki, B.E. Rittmann, C.I. Torres, Importance of OH - transport from cathodes in microbial fuel cells, ChemSusChem 5 (2012) 1071-1079.

[52] J.T. Babauta, H.D. Nguyen, O. Istanbullu, H. Beyenal, Microscale gradients of oxygen, hydrogen peroxide, and $\mathrm{pH}$ in freshwater cathodic biofilms, ChemSusChem 6 (7) (2013) 1252-1261.

[53] I. Ieropoulos, A. Gálvez, J. Greenman, Effects of sulphate addition and sulphide inhibition on microbial fuel cells, Enzym. Microb. Technol. 52 (1) (2013) 32-37.

[54] M. Santini, M. Guilizzoni, M. Lorenzi, P. Atanassov, E. Marsili, S. Fest-Santini, P. Cristiani, C. Santoro, Three-dimensional X-ray micro computed tomography of carbonates and biofilm on operated cathode in single chamber microbial fuel cell, Biointerphases 10 (2015) 031009, http://dx.doi.org/10.1116/1.4930239.

[55] P. Cristiani, M.L. Carvalho, E. Guerrini, M. Daghio, C. Santoro, B. Li, Cathodic and anodic biofilms in single chamber microbial fuel cells, Bioelectrochemistry 92 (2013) $6-13$.

[56] C. Santoro, M. Cremins, U. Pasaogullari, M. Guilizzoni, A. Casalegno, A. Mackay, B. Li, Evaluation of water transport and oxygen presence in single chamber microbial fue cells with carbon-based cathodes, J. Electrochem. Soc. 160 (7) (2013) G128-G134.

[57] X. Feng Oxidation of phenols, anilines, and benzenethiols by fungal laccases: correlation between activity and redox potentials as well as halide inhibition, Biochemistry 35 (1996) 7608-7614.

[58] C. Vaz-Dominguez, S. Campuzano, O. Rüdiger, M. Pita, M. Gorbacheva, S. Shleev, V.M. Fernandez, A.L. De Lacey, Laccase electrode for direct electrocatalytic reduction of $\mathrm{O}_{2}$ to $\mathrm{H}_{2} \mathrm{O}$ with high-operational stability and resistance to chloride inhibition, Biosens. Bioelectron. 24 (2008) 531-537.

[59] R.D. Milton, F. Giroud, A.E. Thumser, S.D. Minteer, R.C.T. Slade, Bilirubin oxidase bioelectrocatalytic cathodes: the impact of hydrogen peroxide, Chem. Commun. 50 (1) (2014) 94-96.

[60] R.D. Milton, F. Giroud, A.E. Thumser, S.D. Minteer, R.C.T. Slade, Glucose oxidase progressively lowers bilirubin oxidase bioelectrocatalytic cathode performance in single-compartment glucose/oxygen biological fuel cells, Electrochim. Acta 140 (2014) 59-64. 